samples are taken at five-minute intervals, and serious trouble can be averted by expediting the delivery. This method of management has proved its value in two of our subsequent cases where a rapid fall in the $\mathrm{pH}$ to a figure below $7 \cdot 15$ was noted soon after the breech had reached the perineum. This indicated rapidly developing anoxia, so modified breech extraction was carried out forthwith, and in each case the baby was in excellent condition.

Significantly, these are the only babies who, despite having a pH of below 7.15, had a one-minute Apgar score of more than 4 and a five-minute score of more than 8 .

Having completed our pilot study, and analysed 13 subsequent cases, we have now evolved the following simple and practical form of management.

Group $A .-\mathrm{pH}$ below $7 \cdot 15$. Another sample is taken at once and if it is confirmed that the level is below 7.15 and immediate delivery is not possible, caesarean section is carried out.

Group B.-pH between $7 \cdot 20$ and $7 \cdot 15$. Five-minute sampling is carried out, but no action is taken unless the $\mathrm{pH}$ approaches $7 \cdot 15$, in which case the delivery is expedited by groin traction.

Group C.- $\mathrm{pH}$ above $7 \cdot 20$. If the five-minute samples remain above this figure no action is necessary and the baby is delivered in the usual manner.

We hope that by delivering a breech in good condition, and avoiding what has hitherto been regarded as harmless asphyxia, that we can obviate the risk of minor degrees of brain damage. Unfortunately, the effects of brain damage are not immediately obvious, but may well manifest themselves in later years. With this in mind we intend to follow up the infants delivered in this series, and we are at present carrying out a follow-up of 250 cases of breech delivery conducted by one of us (J.G.H.) between 1964 and 1966.

We would like to thank the South East Metropolitan Regional Hospital Board for the financial assistance for this research project. We would also like to thank Mr. B. G. Pickles for his enthusiastic co-operation, and we are grateful to the medical staff, both obstetric and paediatric, to the midwives, research assistants, and secretarial staff who have all given such valuable support. We are also indebted to Mr. C. K. Vartan for his valuable advice and encouragement.

\section{References}

Chassar Moir, J., and Myerscough, P. R. (1971). Operative Obstetrics, 8th edn. London, Baillière.

Cox, L. W. (1950). Fournal of Obstetrics and Gynaecology of the British Empire, $51,197$. Dieckmann, W. J. (1946). American fournal of Obstetrics and Gynecology, 52, Donald, I. (1969a). Practical Obstetric Problems, 4th edn., p. 337. London,
Lloyd Luke. Donald, I. (1969b). Practical Obstetric Problems, 4th edn., p. 624. London,

Holland, E. (1920). Transcripts of the Edinburgh Obstetric Society, 40, 112.

Gibberd, G. F. (1931). British Medical fournal, 2, 369

Gibberd, G. F. (1955). Short Textbook of Midwifery, 6th edn. London, Churchill.

Hay, D. (1959). Fournal of Obstetrics and Gynaecology of the British Empire, 66, 529.

Lee, K. H. (1972). Postgraduate Medical fournal, 48, 405.

Payling Wright, G. (1960). Introduction to Pathology, 3rd edn., p. 402. London, Longmans Green.

Saling, E. (1966). Foetal and Neonatal Hypoxia, p. 101. London, Arnold.

Tompkins, P. (1943). American fournal of Obstetrics and Gynecology, 46, 695.

Vartan, C. K. (1945). Fournal of Obstetrics and Gynaecology of the British Empire, 52, 417 .

\title{
Cutaneous Sarcoidosis in Blood Donation Venepuncture Sites
}

\author{
B. W. HANCOCK
}

British Medical fournal, 1972, 4, 706-708

\section{Summary}

Six patients were studied in whom sarcoidosis first showed itself by the development of granulomata at the site of previous venepunctures. The diagnosis was histologically confirmed in all cases. The treatment of the lesions with triamcinolone did not seem to hasten resolution.

\section{Introduction}

The infiltration of old and new cutaneous scars by granulomatous tissue in sarcoidosis is well recognized. Six of 200 patients (James, 1959) and 11 of 275 patients (Scadding, 1967) had infiltration of scars by sarcoid tissue, and this was the most common form of skin sarcoidosis reported from Stockholm (Löfgren and Stavenow, 1961). The scars were usually posttraumatic or postoperative or, occasionally, after inoculations.

Six cases of sarcoid granuloma, all presenting in blood donation venepuncture scars, seemed such a curiously high incidence of a rare presentation that it was regarded as worthy of a report.

\footnotetext{
Rupert Hallam Dermatology Department, Hallamshire Hospital, Sheffield

B. W. HANCOCK, M.B., D.C.H., Senior House Officer
}

\section{Patients}

The histories and findings of the six cases are summarized in Tables I and II.

Of the six patients five were women, and the age of presentation varied from 28 to 53 years. All the patients had received venepunctures when donating blood, in Case 1 as many as 34 donations over 20 years and in Case 3 only one donation four years previously. The period that had elapsed between the last venesection and the first appearance of cubital fossa lesions varied from three days to seven years. The cubital fossa lesions were the only and presenting cutaneous manifestation of sarcoidosis in four patients and in Case 2 were the only manifestation of the disease (Figs. 1-4).

The general health of all patients was good though five showed bilateral hilar lymphadenopathy on chest radiography, but only one of these (Case 5) had any evidence of lung parenchymal involvement, and this without impairment of pulmonary function.

Histology of cubital fossa lesions in all cases showed granuloma formation with epithelioid cells, giant cells, and lymphocytes without evidence of caseation or acid fast bacilli or foreign bodies. Mantoux tests (1/1,000 solution) on five patients were all negative after 48 hours, and the highest erythrocyte sedimentation rate (Westergren) recorded was 16 millimetres in one hour.

In the four earlier cases, three with bilateral hilar lymphadenopathy (Cases 1, 3, and 4), all skin lesions had resolved within 15 months of presentation and, though in Case 1 there was minimal hilar lymphadenopathy at the time of discharge from 
TABLE I-Case Histories of Six Patients Presenting with Sarcoid Infiltration of Venepuncture Sites

\begin{tabular}{|c|c|c|c|c|c|c|c|}
\hline $\begin{array}{l}\text { Case } \\
\text { No. }\end{array}$ & $\begin{array}{l}\text { Sex and } \\
\text { Age }\end{array}$ & Skin Involvement & $\begin{array}{l}\text { Blood Donor } \\
\text { History }\end{array}$ & $\begin{array}{l}\text { Time Since } \\
\text { Last } \\
\text { Venesection }\end{array}$ & Presentation & Lung Involvement & Other Involvement \\
\hline 1 & F. 53 & $\begin{array}{l}\text { Several small nodules } \\
\text { in venesection scars in } \\
\text { left cubital fossa }\end{array}$ & $\begin{array}{l}34 \text { donations, } \\
1945-64\end{array}$ & $\begin{array}{l}\text { Few days } \\
\text { only }\end{array}$ & $\begin{array}{l}\text { Nodule in left cubital fossa } \\
\text { noticed in February } 1964 \text {. } \\
\text { Attended skin clinic July } 1964\end{array}$ & $\begin{array}{l}\text { Slight bilateral hilar } \\
\text { lymphadenopathy. } \\
\text { Pulmonary function } \\
\text { normal }\end{array}$ & $\begin{array}{l}\text { None. } \\
\text { Previous history of } \\
\text { myxoedema. No thyroid } \\
\text { antibodies found }\end{array}$ \\
\hline 2 & F. 33 & $\begin{array}{l}\text { 1-cm nodule with } \\
\text { several papules in } \\
\text { venepuncture sites in } \\
\text { left cubital fossa }\end{array}$ & $\begin{array}{l}29 \text { donations, } \\
1953-68\end{array}$ & 3 months & $\begin{array}{l}\text { Nodule left cubital fossa present } \\
2 \text { months. Attended skin clinic } \\
\text { March } 1969\end{array}$ & None & None \\
\hline 3 & M. 31 & $\begin{array}{l}\text { Nodule on forehead. } \\
1 \text { infiltrated venesection } \\
\text { scar in right cubital } \\
\text { fossa }\end{array}$ & $\begin{array}{l}1 \text { donation, } \\
4 \text { years } \\
\text { previously }\end{array}$ & 4 years & $\begin{array}{l}\text { Presented to a casualty department } \\
\text { with cyst on forehead. } \\
\text { Sarcoidosis diagnosed from } \\
\text { biopsy. Attended skin clinic } \\
\text { February } 1969 \text {. Cubital fossa } \\
\text { lesions present } 2 \text { months }\end{array}$ & $\begin{array}{l}\text { Bilateral hilar } \\
\text { lymphadenopathy. } \\
\text { Pulmonary function } \\
\text { normal }\end{array}$ & None \\
\hline 4 & F. 28 & $\begin{array}{l}\text { Infiltrated venesection } \\
\text { scars (about } 9 \text { ) in left } \\
\text { cubital fossa }\end{array}$ & $\begin{array}{l}15 \text { donations, } \\
1960-70\end{array}$ & 1 year & $\begin{array}{l}\text { Induration of venesection scars } \\
\text { for } 3 \text { months. } \\
\text { Attended skin clinic April } 1970\end{array}$ & $\begin{array}{l}\text { Early bilateral hilar } \\
\text { lymphadenopathy }\end{array}$ & $\begin{array}{l}\text { None } \\
\text { Developed sarcoid in } \\
\text { Mantoux inoculation }\end{array}$ \\
\hline 5 & F. 47 & $\begin{array}{l}\text { Infiltrated scars left knee } \\
\text { and right eyebrow. } \\
\text { Small infiltrated nodules } \\
\text { in venesection scars right } \\
\text { cubital fossa }\end{array}$ & $\begin{array}{l}4 \text { donations, } \\
1962-5\end{array}$ & 7 years & $\begin{array}{l}\text { Induration of venesection scars } \\
\text { for } 3 \text { months. Attended skin } \\
\text { clinic April } 1972\end{array}$ & $\begin{array}{l}\text { Bilateral hilar } \\
\text { lymphadenopathy. } \\
\text { Faint lung nodularity }\end{array}$ & None \\
\hline 6 & F. 29 & $\begin{array}{l}\text { Several infiltrated } \\
\text { venesection scars in left } \\
\text { cubital fossa }\end{array}$ & $\begin{array}{l}17 \text { donations, } \\
1961-71\end{array}$ & 2 years & $\begin{array}{l}\text { Attended June } 1972 \text { medical } \\
\text { outpatient department. Hilar } \\
\text { lymphadenopathy noted } 1969 \text {. } \\
\text { Antecubital fossa lesions present } \\
\text { for } 9 \text { months }\end{array}$ & $\begin{array}{l}\text { Bilateral hilar } \\
\text { lymphadenopathy }\end{array}$ & $\begin{array}{l}\text { Paraesthesiae for } 2 \text { years } \\
\text { in both hands. Of } \\
\text { uncertain significance }\end{array}$ \\
\hline
\end{tabular}

TABLE II-Investigations and Progress of the Six Patients Under Review

\begin{tabular}{|c|c|c|c|}
\hline $\begin{array}{l}\text { Case } \\
\text { No. }\end{array}$ & Investigations & Histology & Progress \\
\hline 1 & $\begin{array}{l}\text { E.S.R. } 16 \mathrm{~mm} / 1 \mathrm{hr} \text {. } \\
\text { Mantoux }(1-1,000) \text {-ve }\end{array}$ & $\begin{array}{l}\text { Follicles with epithel- } \\
\text { ioid cells, giant cells, } \\
\text { and lymphocytes. No } \\
\text { caseation. }\end{array}$ & $\begin{array}{l}\text { Skin changes resolved over } \\
12 \text { months. Hilar lympha- } \\
\text { denopathy minimal at time } \\
\text { of discharge. Treatment- } \\
\text { intralesional triamcinolone }\end{array}$ \\
\hline 2 & $\begin{array}{l}\text { E.S.R. } 11 \mathrm{~mm} / 1 \mathrm{hr} \text {. } \\
\text { Mantoux }(1-1,000) \text {-ve }\end{array}$ & $\begin{array}{l}\text { Giant cells, } \\
\text { epithelioid cells, and } \\
\text { lymphocytes. } \\
\text { No caseation. }\end{array}$ & $\begin{array}{l}\text { Resolved over } 6 \text { months. } \\
\text { Resumed donating } 1971\end{array}$ \\
\hline 3 & $\begin{array}{l}\text { Kveim + ve } \\
\text { Mantoux } \\
\quad(1-1,000)-\text { ve } \\
\text { E.S.R. } 6 \mathrm{~mm} / 1 \mathrm{hr} \text {. }\end{array}$ & $\begin{array}{l}\text { Granuloma with some } \\
\text { necrosis. } \\
\text { No caseation }\end{array}$ & $\begin{array}{l}\text { Skin and lung changes } \\
\text { returned to normal over } \\
15 \text { months }\end{array}$ \\
\hline 4 & Mantoux & $\begin{array}{l}\text { Epithelioid cells, } \\
\text { giant cells, and } \\
\text { lymphocytes. }\end{array}$ & $\begin{array}{l}\text { Skin and lung changes } \\
\text { resolved over } 9 \text { months. } \\
\text { Treatment- }\end{array}$ \\
\hline 5 & $\begin{array}{l}\text { E.S.R. } 16 \mathrm{~mm} / 1 \mathrm{hr} \text {. } \\
\text { Mantoux } \\
\qquad(1-1,000)-\text { ve }\end{array}$ & $\begin{array}{l}\text { No caseation } \\
\text { Epithelioid cells, } \\
\text { lymphocytes, and } \\
\text { giant cells in } \\
\text { granulomas. }\end{array}$ & $\begin{array}{l}\text { intralesional triamcinolone } \\
\text { Lesions unchanged after } \\
6 \text { months follow-up }\end{array}$ \\
\hline 6 & $\begin{array}{l}\text { E.S.R. } 7 \mathrm{~mm} / 1 \mathrm{hr} . \\
\text { Kveim + ve }\end{array}$ & $\begin{array}{l}\text { No caseation. } \\
\text { Epithelioid cells, } \\
\text { lymphocytes, and } \\
\text { giant cells in } \\
\text { granulomas. } \\
\text { No caseation. }\end{array}$ & $\begin{array}{l}\text { Lesions unchanged after } \\
3 \text { months follow-up. }\end{array}$ \\
\hline
\end{tabular}

follow-up, the lung lesions in the other two patients had resolved completely. The lung and skin lesions of Cases 5 and 6 , with follow-up of only six months and three months respectively, remained essentially unchanged. Intralesional triamcinolone did not seem to hasten resolution of the skin lesions. In the two patients (Cases 1 and 4) so treated the lesions resolved after 12 and nine months respectively, and during this period the hilar lymphadenopathy in Case 4 also resolved.

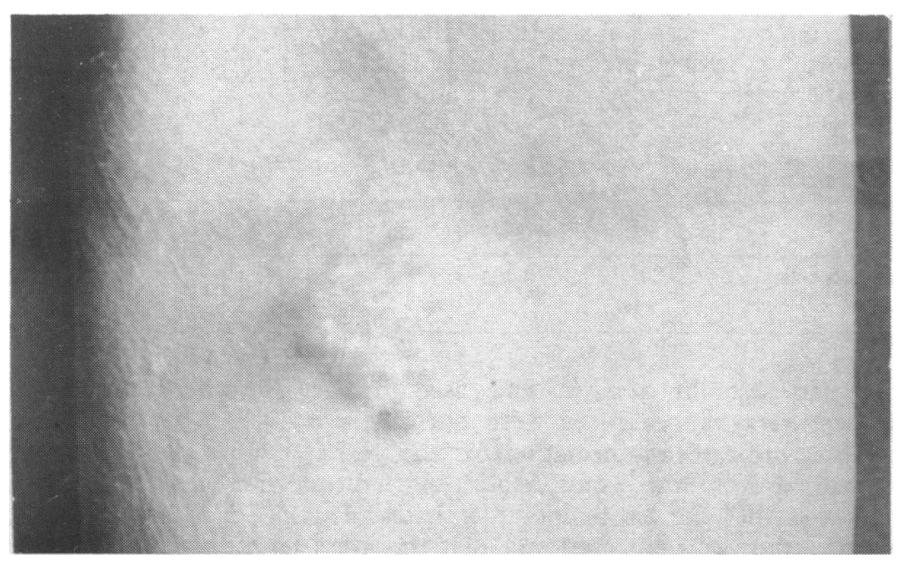

FIG. 1-Case 1. Sarcoidosis in left cubital fossa venepuncture scars.

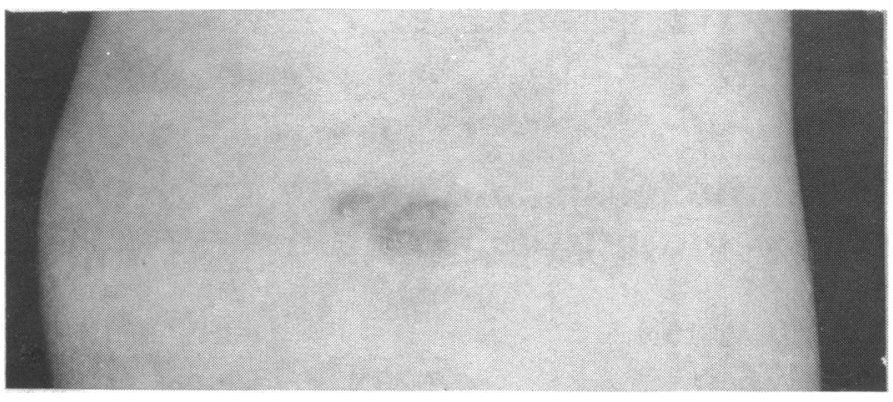

FIG. 2-Case 2. Sarcoidosis in left cubital fossa venepuncture scars.

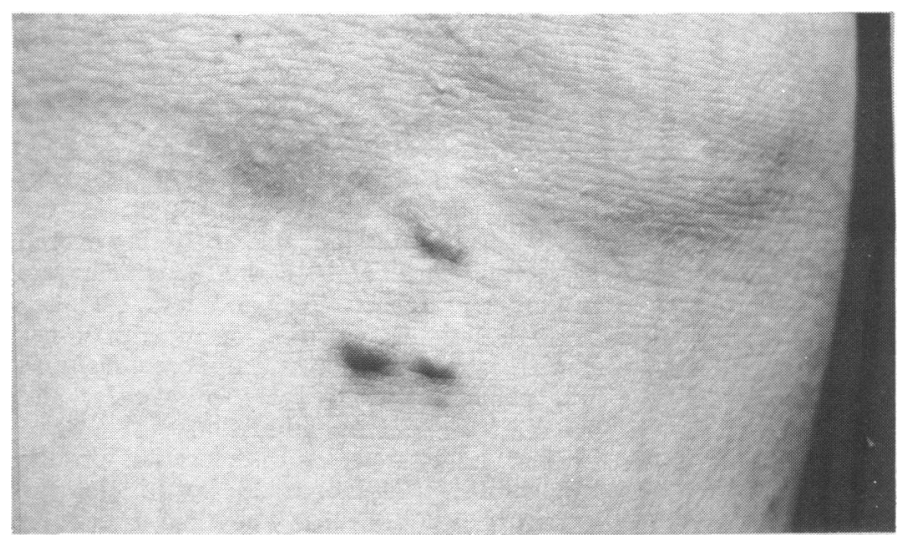

FIG. 3-Case 5. Sarcoidosis in right cubital fossa venepuncture scars.

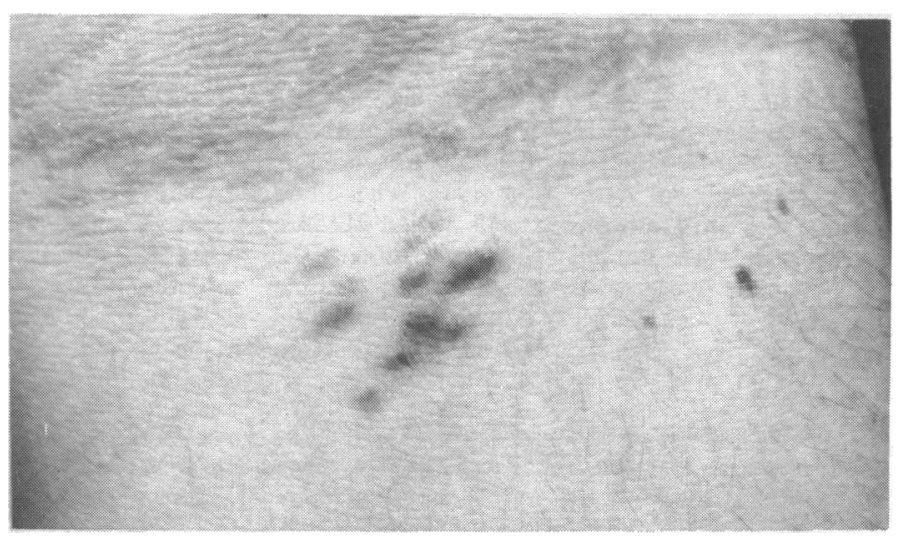

FIG. 4-Case 6. Sarcoidosis in left cubital fossa venepuncture scars. 


\section{Comment}

The sex distribution of patients in the series (five women to one man) shows a female preponderance in contrast to the equal sex distribution in previous series of sarcoidosis in scar tissue (James, 1959, Scadding, 1967). The mean age of onset (37 years) and age range (28-53 years) agree closely with other figures for scar sarcoid involvement (Scadding, 1967).

Scar infiltration by sarcoid tissue has been thought to result either from previous contamination by foreign material in a favourable matrix (Löfgren et al., 1955) or as a hypersensitivity reaction akin to erythema nodosum (James, 1959) occurring at the time of sarcoid activity elsewhere in the body. There was no histological evidence of foreign material contamination in any of the present six patients but the venesection sites did become infiltrated at the time of lung sarcoid involvement in five cases, suggesting that the scar tissue provided a favourable matrix when the sarcoidosis was most active. The venepuncture needles used in all cases, so far as could be ascertained, did not contain metals, such as beryllium and zirconium, likely to give granulomatous reaction.

All these patients exhibited features typical of sarcoid involvement in scars (Scadding, 1967) in that infiltration occurred early in the disease before major lung parenchymal involvement, and that in the four earlier cases the skin changes tended to follow the course of lung changes with good prognosis for complete recovery.

I should like to thank Dr. I. B. Sneddon for his helpful criticism, and Dr. Sneddon, Dr. R. E. Church, Dr. S. S. Bleehen, and Dr. J. J. Daly for permission to report details of patients under their care.

\section{References}

James, D. G. (1959).Quarterly fournal of Medicine, 28, 109.

Lofgren, S., and Stavenow, S. (1961). American Review of Respiratory Disease, 84, 71. Lofgren, S., Snelliman, B., and Nordenstam, H. (1955). Acta Chirurgica
Scandinavica, 108, 405.

Scadding, J. G. (1967). Sarcoidosis. London, Eyre \& Spottiswoode.

\section{MEDICAL MEMORANDA}

\section{Mononucleosis and the Miniskirt: An Incompatible Combination}

\section{T. J. HAMBLIN}

British Medical fournal, 1972, 4, 708-709

The dangers of being out on a spring night in a miniskirt are not the only ones that leap immediately to mind.

\section{Case History}

An attractive 19-year-old girl presented in April 1970 wearing an extremely short miniskirt barely covering the buttocks. She gave a one-week history of pruritus and tenderness over both legs. For three or four days she had complained of slight malaise. On rising on the morning before admission she had discovered blackened areas over the lateral aspect of both thighs, which were painful and tender and gradually turned blue and red. She had not noticed any changes in her fingertips, toes, or the tip of her nose. Apart from childhood exanthemata her only previous rash had been after receiving penicillin seven years previously, and she had not received penicillin before this admission.

When in hospital she had large areas of discoloration on the outer aspect of both thighs measuring about 25 by $15 \mathrm{~cm}$, the upper edges close to the hem of her miniskirt. They had a reticular pattern, being navy-blue in the centre and becoming purple, red, and rust-coloured moving outwards towards the edge (see Fig.). The lesions were shiny, raised above the surrounding skin, not ulcerated, but tender and painful. There were similar but much smaller patches on the outer aspect of each arm. She was apyrexial and had no other abnormal signs; in particular her fauces were normal and there was no lymphadenopathy or splenomegaly.

On the day of admission the haemoglobin was $13.7 \mathrm{~g} / 100 \mathrm{ml}$, the W.B.C. was $8,350 / \mathrm{mm}^{3}$, platelets were $126,000 / \mathrm{mm}^{3}$, and the E.S.R. was $4 \mathrm{~mm}$ in the first hour. The blood film showed spontaneous agglutination of red cells which obscured their morphology, although no fragmented cells were noted. Many atypical mononuclear cells were seen. A screening test for infectious mononuceosis was positive. Next day the haemoglobin was $14.3 \mathrm{~g} / 100 \mathrm{ml}$, the W.B.C. was $8,900 / \mathrm{mm}^{3}, 72 \%$ abnormal mononuclears, platelets were $94,000 / \mathrm{mm}^{3}$, reticulocytes were $1.5 \%$, and urea and electro-

Departments of Medicine and Pathology, Southmead Hospital, Bristol

T. J. HAMBLIN, M.B., M.R.C.P., (present appointment: Senior Registrar Poole, Dorset). lytes were normal. Bilirubin was $1 \mathrm{mg} / 100 \mathrm{ml}$, alkaline phosphatase was 32 K.A. units, and alanine transferase was 60 units. Schum's test for methaemalbumin was negative. The prothrombin ratio was 1-3 (control $10 \mathrm{sec}$.), and the activated partial thromboplastin

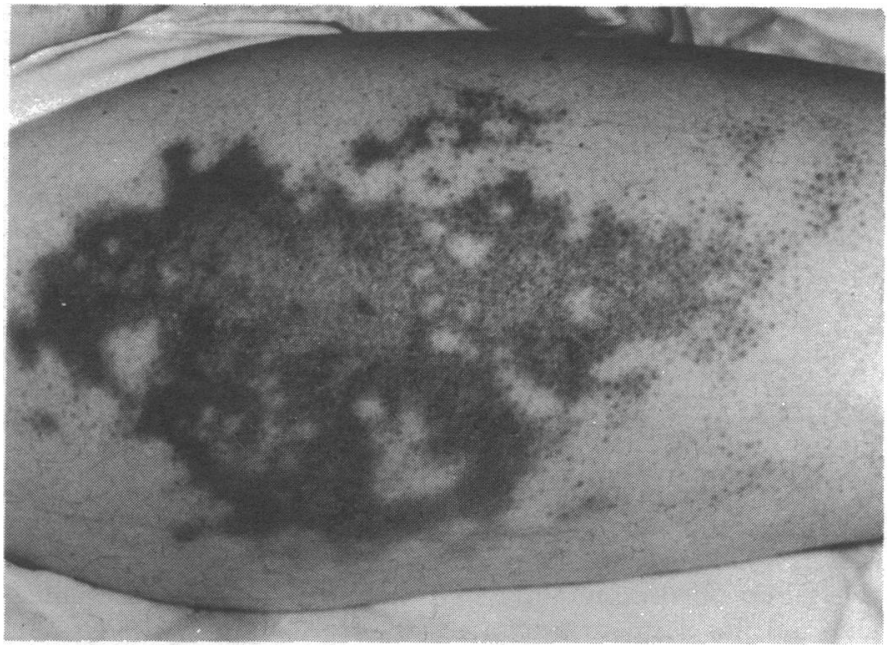

Patient's right thigh on day after admission.

time $68 \mathrm{sec}$. (control $31 \mathrm{sec}$.). L. E. cells were negative. Rheumatoid factor was positive. Paul-Bunnell-Davidsohn test showed antibody against sheep red blood cells present to a titre of 512. The antibody was removed after absorption with ox erythrocytes but not after absorption with guinea-pig kidney. Cold agglutinin titres at various temperatures are given in the Table.

Titres of Adult and Cord Cells at Various Temperatures

\begin{tabular}{|c|c|c|c|c|c|}
\hline & & $4^{\circ} \mathrm{C}$ & $20^{\circ} \mathrm{C}$ & $32^{\circ} \mathrm{C}$ & $37^{\circ} \mathrm{C}$ \\
\hline $\begin{array}{l}\text { Adult cells } \\
\text { Cord cells }\end{array}$ & $\begin{array}{ll}\because . & . .\end{array}$ & $\begin{array}{r}512 \\
64\end{array}$ & 64 & $\begin{array}{l}8 \\
0\end{array}$ & o \\
\hline
\end{tabular}

Urinary urobilinogen was increased, urinary bilirubin was absent. Chest $x$-ray appearances were normal.

Meteorological information for the period before the illness was obtained from the Long Ashton Agricultural Research Station. It showed that the air temperature had fallen to $1.5^{\circ} \mathrm{C}$ on the night before the rash appeared and that the grass temperature had fallen to $-3^{\circ} \mathrm{C}$. Nearly $\frac{1}{2}$ in $(1.3 \mathrm{~cm})$ of rain had fallen during the day. 